\title{
Convergence Dynamics between South Africa and Her Main Trading Partners
}

\author{
Ntombiyesibini Matonana \\ Nelson Mandela University, South Africa \\ s215336348@mandela.ac.za \\ Andrew Phiri \\ Nelson Mandela University, South Africa \\ phiricandrew@gmail.com
}

The convergence of per capita GDP growth rates of less developed countries towards those of more industrialized economies is a central debate amongst growth economists. This study contributes to the literature by examining whether South Africa, as arguably Africa's most developed economy, converges towards the growth of her main trading partners (i.e. Belgium, Botswana, China, Germany, India, Japan, Mozambique, Namibia, Netherlands, South Korea, United Arab Emirates (UAE), United Kingdom (UK), United States (Us), Zambia and Zimbabwe). To this end, we examine the integration properties of per capita GDP differences between South Africa and each of her trading partners and we particularly employ unit root testing procedures which are robust to ESTAR-type nonlinearities and unobserved smooth structural breaks. Our empirical evidence points to convergence between South Africa and Belgium, Botswana, China, Germany, India, Japan, Mozambique, Namibia, Netherlands, South Korea, the UAE, the UK and the Us but not with Zambia and Zimbabwe.

Key Words: convergence, Flexible Fourier Form (F F F) unit root tests, unobserved structural breaks, asymmetries, South Africa

JEL Classification: C21, C22, C51, C52, O 47

https://doi.org/10.26493/1854-6935.18.25-44

\section{Introduction}

Economic growth convergence has formed part of the major themes of local and international trade summits and is one of the most studied phenomenon's in the macroeconomics paradigm. The growth convergence phenomenon hypothesizes on poor countries having a larger potential to grow faster than developed countries and will thus 'catch-up' to the steady state of initially rich countries (Rebelo 1991). In essence, neoclassical theorists predict absolute convergence of countries to the same path of growth and income per capita, where poor countries catch-up to the 
economic growth levels of the more industrialised and developed countries assuming that these countries have similar characteristics such as the same population growth rates, the same savings rate, the same rate of technological progress, and the same rate of capital accumulation (Baumol 1986; Barro and Sala-i-Martin 1992; Mankiw, Romer, and Weil 1992). However, new growth economists have criticised neoclassical theorists for failing to explain the basic facts of actual growth behaviour over the last century and argue that endogenous factors play a more significant role in the economic growth process (Romer 1986; 1990; Sokoloff and Engerman 2000).

The macroeconomic theory of convergence is connected to the topic of long-term economic growth and understanding the factors that influence the different growth patterns between countries. This comes with the belief that economic growth depends on the expansion of certain key factors of the economy and that structural changes between countries may provide an explanation for the observed growth rate differences across countries. The empirical literature is filled with a plethora of studies which seek to examine the convergence hypothesis in both developed and developing countries, however, with little conclusiveness being achieved in the convergence debate. In one of the earlier studies, Barro (1991) confirmed convergence effects through a beta convergence analysis using a uniquely formed beta convergence model estimated with panel data regression techniques. This paved the way for many more studies around the convergence hypothesis with authors including Friedman (1992), Quah (1993), Bernard and Durlauf (1996) and Evans and Karras (1996) suggesting a different approach to studying convergence by focusing on the integration properties of income disparities across countries as opposed to a model which assumes a negative and statistically significant relationship between real GDP per capita over time and the economic level measured by the initial per capita GDP variable (Arbia, Basile, and Piras 2005).

Our current study focuses on the convergence growth path between South Africa, as one of Africa's largest and most sophisticated economies, and a select number of its biggest trading partners. With its wealth in natural resources and a diversified economic state, South Africa is a country with great growth potential. While many have described it as a blend of first and third world economies, South Africa remains an anomaly among developed countries. Despite being one of Africa's richest economies, the country currently threads on an undesirable developmental path riddled with immense economic and social maladies, most a clear by-product of 
the legacy of apartheid, whose repercussions are setting the country back from achieving its full development potential. This paper assesses South Africa's growth performance with its top trading partners in the context of the economic convergence affirmed by Baumol (1986) and fueled by Paul Romer's (1986) production-technology-based endogenous growth theory with increasing returns to scale, which has a strong tendency for wealthy countries to maintain or increase their lead over countries with a lower level of development (Sachs and Warner 1995). Our study particularly draws from the study of Ben-David (1996) who hypothesizes on developing countries with high levels of trade and openness should, via the factor price equalization theorem, inducing the equalization of income towards that of more industrialized trading partners.

Our study also recognizes common fallacies in quantitative methodology used in economic convergence literature which tend to rely on traditional unit root testing procedures such as the ADF and PP tests which have been criticised on the premise of failing to account for existing structural breaks and asymmetries which, in turn, leads to a bias that reduces the ability of these tests to distinguish between a unit root and a closeto-unit root process (Perron 1990 and Kapetanois, Shin, and Snell 2001). To remedy such problems, Enders and Lee (2012) introduced the Flexible Fourier Form ( F F F) unit root test as an alternative that allows for existing structural breaks and captures nonlinearities and unobserved smooth structural breaks.

The testing procedure used in this paper is borrowed from the works of Christopoulos and Leon-Ledesma (2010) who combine the FFF framework in conjunction with the exponential smooth threshold autoregressive (ESTAR) framework. The purpose of this paper is to examine whether the per capita GDP growth of South Africa converges towards that of its top 15 trading partners. In other words, our study is concerned with testing the hypothesis that open economies reap welfare benefits and should grow towards a similar growth paths to that of more developed trading partners. Notably, testing growth convergence between South Africa and its trading partners presents itself as an interesting area of research since it has not been previously addressed. This study makes a significant contribution to empirical literature as the first study to examine the convergence phenomenon for South Africa with its developed trading partners.

The remainder of this paper is as follows: the second section is the literature review, the third section provides the methodology used in the 
study, the fourth section presents the empirical results while the fifth section provides the concluding remarks to the study.

\section{Literature Review}

Neoclassical and new growth theories form the basis of the phenomenon of growth convergence. The neoclassical growth theory faces major criticism for failing to explain actual growth behaviour and for its general assumptions. The theory assumes that countries use the same production function, an assumption which ignores international and structural differences in terms of inputs and processes used in production in different countries. Secondly, the supposed unconditional convergence in per capita growth rates does not seem to hold over long periods of time across nations (McCallum 1996) and thus it has been refuted in the works of Barro (1991) and Quah (1996). On the contrary, the new growth theory set on Verdoorn's law emphasizes endogenous technological progress and externalities and favours conditional convergence. Verdoorn's law describes a simple long-run relation between productivity and output growth which states that there is a direct spillover relationship between higher output growth and productivity growth in the long-run due increasing returns to scale. Advocates of the new-growth theory criticise the neoclassical growth theory stating that endogenous factors play a more significant role in economic growth (Sokoloff and Engerman 2000).

Early convergence theorists believed that developing countries have the potential to grow at a rate faster than developed countries because diminishing returns are not as strong as in capital-rich countries and poor countries can easily replicate the production methods, technologies, and institutions of developed countries. Some believed that for convergence to occur, countries must have the necessary social capabilities including involvement in global markets, technological innovation, and the ability to attract capital in order for them to benefit from catch-up growth (Abramovitz 1986). According to Abramovitz (1986), these prerequisites explain why there is still divergence in the world today.

Empirical literature provides a plethora of findings on the convergence hypothesis for countries in Africa and abroad. Baumol's (1986) study is one of the first studies conducted in the convergence debate. The study tested the theory of unconditional convergence by performing a univariate growth regression and analysing real per capita incomes from 1870 to 1979 for the Maddison 16 industrialised countries, namely; Australia, Austria, Belgium, Canada, Denmark, France, Finland, Germany, 
Italy, Japan, Netherlands, Norway, Sweden, Switzerland, United Kingdom, United States. Although the evidence suggests convergence for the countries, Baumol (1986) finds it difficult to draw a collective inference. An extension of the study based on 72 countries for the period 1950 to 1980 with a focus on GDP per capita growth shows no evidence of convergence. By grouping the countries Baumol (1986) argues that the 16 industrialised countries in his initial regression are not the only group that has converged; suggesting more than one convergence club. However, De Long (1988) critiques that Baumol's study suffers from sample selection bias because the study involved a selection of countries that were relatively rich and had already converged in 1870 and any nation that was relatively rich in 1870 but did not converge, failed reach the Maddison sixteen group of countries. De Long (1988) modified the statistical bias by adding six additional countries to the Maddison's 16; Argentina, Chile, Ireland, New Zealand, Portugal, Spain, and then East Germany. Contrary to Baumol's (1986) findings, De Long's (1988) analysis finds that estimates of early per capita growth for a wider less biased sample of countries exhibits little sign of convergence.

Barro's (1991) study made a significant contribution to empirical literature on the convergence debate. Barro (1991) confirmed convergence effects through a beta convergence analysis using a uniquely formed beta convergence model with panel data regression techniques. This paved the way for other studies on the convergence hypothesis with authors including Friedman (1992), Quah (1993), Bernard and Durlauf (1996) and Evans and Karras (1996) suggesting a different approach studying convergence focusing on the stationarity of income disparities across countries as opposed to a model which assumes a negative and statistically significant relationship between real GDP per capita over time and the economic level measured by the initial per capita GDP variable (Arbia, Basile, and Piras 2005). The authors argued that sigma convergence reflects the actual convergence more accurately than beta convergence.

Only few studies have been conducted to examine macroeconomic convergence in African countries (Khan and Kumar 1993; Harvey 2000; Yao and Zhang 2001; McCarthy and Du Plessis 2001; Sachs, Bajpai, and Ramiah 2002; Paap, Franses, and van Dijk 2005; Rossouw 2006; Cuñado and Pérez de Gracia 2006; Burgess 2009; Zyuulu 2010), very few of which have used the time series method (McCoskey 2002; Dobson, Goddard, and Ramlogan 2003; Guetat and Serranito 2007; Charles, Darné, and Hoarau 2010; Nwosu et al. 2013; Hammouda et al. 2007; Hadizadeh 2019). 
Firstly, Harvey (2000) investigates the macroeconomic convergence in SADC member countries in an attempt to establish whether Free Trade Agreements (FTA), the SADC in particular need macroeconomic convergence in order to succeed. Harvey argues that the establishment of an FTA is not reliant on macroeconomic policy convergence although it is necessary for sustaining the F TA over time. Additionally, Burgess (2009) reiterates that achieving the FTA's objectives may be neither necessary nor sufficient to achieve good macroeconomic results and the absence in sustained political commitment, the irregular growth path of national economies in addition to other factors hinder the macroeconomic convergence potential, thus, countries need to coordinate their economies policies to achieve maximum benefits otherwise not possible (Zyuulu 2010).

McCarthy and Du Plessis (2001) emphasize three distinct concepts of convergence: the long run economic convergence or 'catch up'-growth; macroeconomic convergence; and convergence in macroeconomic policies. Studies in empirical literature have equally investigated all the abovementioned types of convergence. McCoskey (2002) examines the convergence of 37 Sub-Saharan African countries using Im, Pesaran, and Shin (2003) panel unit root test and the McCoskey and Kao (1998) panel cointegration test. McCoskey finds no evidence of time series convergence across the used sample for the real GDP-based variables. Dobson, Goddard, and Ramlogan (2003) investigate the process of cross-country growth and convergence in a sample of 80 countries in the developing world by using dynamic panel unit root tests to test the convergence hypothesis. The study uses the variable real per capita GDP covering the period 1960-1995 grouping the 8o countries into regions; Asia/Pacific, Africa and Latin America/Caribbean. Dobson, Goddard and Ramlogan (2003) report that the results establish that convergent behaviour is close to none for the Asia/Pacific region, there is little convergence in certain countries within the Africa and Latin America/Caribbean regions. Overall the results appear to be in favour of some of the main hypotheses of both neo-classical and new growth theories.

In the same vein, Charles, Darné, and Hoarau (2010) test the possibility of stochastic convergence of real per capita GDP for a set of Eastern and Southern African countries belonging to the COMESA free trade agreement using the panel unit-root tests developed by Levin, Lin, and Chu (2002), Im, Pesaran, and Shin (2003) and Bai and Ng (2004). The authors establish that there is no existing stochastic convergence for the COMESA 
countries. While, Nwosu et al. (2013) study tests Total Factor Productivity convergence in Africa with data spanning between 1960 and 2003 using a panel unit root method. This particular study stems from a generally accepted evidence of growth in per capita income and GDP as a result of growth in TFP and subsequent growth of neighbouring countries. The findings of this study find zero evidence of unconditional TFP convergence in Africa contrary to claims of exogenous growth theorists. Notably, little attention has been concentrated to the convergence hypothesis among the countries within African continent. On this subject, Hammouda et al. (2007) makes a significant contribution to empirical literature. Hammouda et al. (2007) investigate the convergence of macroeconomic convergence and its relationship to economic growth in the following regional economic communities in Africa; SADC, COMESA, ECOWAS, CEMAC and UEMOA for a quarterly period spanning between 1987 and 2004. A various number of methods is used in this study, including cross-country dispersion, Unit root testing (DGLS unit root test and the IP s panel unit root test), and cointegration analysis. The study finds that although there appears to be evidence of macroeconomic convergence in the various African RECS, it does not translate to expected higher growth levels. This is supported by the fact that although the various communities displayed a stable macroeconomic setting in the recent years, there is very little growth associated with it, a reality the paper attributes to the many internal and external challenges Africa still finds itself in.

More recently, Hadizadeh (2019) studies the convergence club hypothesis among MENA countries for the period 1990-2015. This study somewhat relates to that of Guetat and Serranito (2007) on income convergence on MENA countries between 1960-1990 and 1960-2000. The researchers establish existence of convergence for the sample for both periods. While Hadizadeh's (2019) study on club convergence finds that six of the 15 MENA countries form a high-income club and the remaining nine form a low-income club. Whereas a majority of researchers employ traditional unit root tests to test for convergence, in this study we employ a Fourier-based unit tests to strengthen the power of our estimation results.

\section{Trade Relations between South Africa and Its Trading Partners}

According to the World Bank classification of countries, South Africa ranks as an upper-middle income country along with its trading partners Botswana, China, and Namibia. Eight of the 15 trading partners included 
in this study, namely; Belgium, Germany, Japan, Netherlands, South Korea, United Arab Emirates, United Kingdom, and United States are classified as high income countries; while India, Mozambique, Zambia and Zimbabwe are listed as lower-middle income countries. Together these economies received about $64.4 \%$ of South African exports in 2018. Table 1 shows the ranking of the countries from the first to the 15th top trading partner.

South Africa's growth is often compared with some developed and newly industrialised countries in the upper middle-income and highincome categories; such as China, Japan, and many OECD and EU member countries. Within the EU, Germany, United Kingdom, Netherlands, and Belgium are South Africa's biggest and most important trading partners. The four countries are South Africa's biggest export destinations in the $\mathrm{EU}$, with Germany being the biggest trading partner in the $\mathrm{EU}$ followed by the United Kingdom, Netherlands, and Belgium. In 2018, Belgium, South Africa's fourth largest trading partner in the EU received exports worth Us $\$ 2.44$ Billion from South Africa and imported U $\$ 1.05$ Billion worth of goods to South Africa (United Nations Comtrade, 2018). The country vowed to elevate trade relations with South Africa, signing a memorandum of understanding on enhanced cooperation which includes joint commission on bilateral trade agreements and intensity on economic ties between the two. Belgium has remained a top trading partner for South Africa and is among the country's top 10 investors from the EU. Whereas, relations between South Africa and the Netherlands can be traced back to 1652 when the Dutch East India Company, arguably the greatest and most successful company in history, created a trading post in Cape Town. Since then, relations between South Africa and the Netherlands have particularly strengthened since 1990.

In the same high-income category Japan, South Korea, United Arab Emirates, and the United States are among South Africa's top trading partners in the developed first world. The United States and UAE are committed to promoting international trade with South Africa. The Us is one of South Africa's key trading partners in the world and the two countries have enjoyed a solid bilateral trade relationship which has maintained a consistent pattern of expansion since 1994. The UAE and South Africa strengthened their economic ties and have taken trade and economic relations to a higher level since they established formal diplomatic ties in 1994. The two countries have further committed to expanding cooperation in exploiting opportunities in the ocean economy, promoting ex- 
TABLE 1 South Africa's Top 15 Trading Partners

\begin{tabular}{|c|c|c|c|c|}
\hline Country $\mathrm{Ex}$ & Exports & Imports & Import goods & Export goods \\
\hline China & 8.54 & 17.08 & $\begin{array}{l}\text { Plastics, machinery, nuclear } \\
\text { reactors, boilers, articles of } \\
\text { iron and steel }\end{array}$ & $\begin{array}{l}\text { Yarn and fabric, iron and } \\
\text { steel, animal hair, ores slag } \\
\text { and ash }\end{array}$ \\
\hline Germany & 6.7 & 9.12 & $\begin{array}{l}\text { Commodities, Vehicles, } \\
\text { machinery, electric and } \\
\text { electronic equipment }\end{array}$ & $\begin{array}{l}\text { Vehicles, earls, metals and } \\
\text { precious stones, ores slag } \\
\text { and ash }\end{array}$ \\
\hline $\begin{array}{l}\text { United } \\
\text { States }\end{array}$ & 6.4 & 5.53 & $\begin{array}{l}\text { Machinery, nuclear reactors } \\
\text { and boilers, vehicles, elec- } \\
\text { tric and electronic equip- } \\
\text { ment }\end{array}$ & $\begin{array}{l}\text { Iron and steel, mineral } \\
\text { products, precious metals, } \\
\text { vegetable products }\end{array}$ \\
\hline $\begin{array}{l}\text { United } \\
\text { Kingdom }\end{array}$ & 4.81 & 8.05 & $\begin{array}{l}\text { Pearls and precious stones, } \\
\text { edible fruits and nuts, vehi- } \\
\text { cles }\end{array}$ & $\begin{array}{l}\text { Pearls and precious stones, } \\
\text { vehicles, edible fruits and } \\
\text { nuts }\end{array}$ \\
\hline Japan & 4.48 & 2.85 & $\begin{array}{l}\text { Machinery, nuclear reac- } \\
\text { tors, rubbers, iron and steel, } \\
\text { commodities (not specified } \\
\text { to kind) }\end{array}$ & $\begin{array}{l}\text { Pearls, precious stones } \\
\text { and metals, iron and steel, } \\
\text { aluminium }\end{array}$ \\
\hline India & 4.42 & 3.85 & $\begin{array}{l}\text { Vehicles, pharmaceutical } \\
\text { products, mineral fuels and } \\
\text { oils }\end{array}$ & $\begin{array}{l}\text { Mineral fuels, oils and dis- } \\
\text { tillation products, machin- } \\
\text { ery, inorganic chemicals }\end{array}$ \\
\hline Botswana & 4.07 & 3.87 & $\begin{array}{l}\text { Plastics and rubber, live an- } \\
\text { imals, machinery, precious } \\
\text { metals and stones }\end{array}$ & $\begin{array}{l}\text { Mineral products, ma- } \\
\text { chinery, precious metals, } \\
\text { prepared foodstuffs }\end{array}$ \\
\hline Namibia & 3.56 & 0.94 & $\begin{array}{l}\text { Pearls, precious stones, live } \\
\text { animals, meat and seafood, } \\
\text { ships and the floating struc- } \\
\text { ture }\end{array}$ & $\begin{array}{l}\text { Electrical and electronic } \\
\text { equipment, articles of iron } \\
\text { and steel, beverages }\end{array}$ \\
\hline Mozambique & de 3.22 & 0.98 & $\begin{array}{l}\text { Aluminium, ores slag and } \\
\text { ash, edible fruits, printed } \\
\text { books and material }\end{array}$ & $\begin{array}{l}\text { Mineral fuels and oils, ma- } \\
\text { chinery, iron and steel }\end{array}$ \\
\hline Netherlands & 3.1 & 1.15 & $\begin{array}{l}\text { Machinery, mineral fuels } \\
\text { and oils, plastics, animal } \\
\text { and vegetable products, } \\
\text { organic chemicals }\end{array}$ & $\begin{array}{l}\text { Edible fruits, inorganic } \\
\text { chemicals, ores slag and } \\
\text { ash, iron and steel }\end{array}$ \\
\hline
\end{tabular}

Continued on the next page

port of South African agricultural products and manufactured products. In the Asian region, China remains South Africa's biggest trading partner and is South Africa's top trading partner in the world taking U $\$ 8.54$ 
TAB LE 1 Continued from the previous page

\begin{tabular}{|c|c|c|c|c|}
\hline Country & Exports & Imports & Import goods & Export goods \\
\hline Belgium & 2.44 & 1.05 & $\begin{array}{l}\text { Miscellaneous chemical } \\
\text { products, plastics, mineral } \\
\text { fuels, distillation products }\end{array}$ & $\begin{array}{l}\text { Vehicles, pearls, metals and } \\
\text { precious stones, iron and } \\
\text { steel }\end{array}$ \\
\hline Zambia & 2.42 & 2.73 & $\begin{array}{l}\text { Machinery, fertilizers, plas- } \\
\text { tics, electrical and elec- } \\
\text { tronic equipment }\end{array}$ & $\begin{array}{l}\text { Machinery, vehicles, plas- } \\
\text { tics, iron and steel }\end{array}$ \\
\hline Zimbabwe & 2.31 & 0.27 & $\begin{array}{l}\text { Tobacco and tobacco sub- } \\
\text { stitutes, iron and steel, } \\
\text { cotton, edible fruits }\end{array}$ & $\begin{array}{l}\text { Machinery, fertilizers, iron } \\
\text { and steel, electrical and } \\
\text { electronic equipment }\end{array}$ \\
\hline $\begin{array}{l}\text { South } \\
\text { Korea }\end{array}$ & 1.9 & 1.05 & $\begin{array}{l}\text { Vehicles, electric and elec- } \\
\text { tronic equipment, organic } \\
\text { chemicals }\end{array}$ & $\begin{array}{l}\text { Mineral fuels and oils, vehi- } \\
\text { cles, organic chemicals }\end{array}$ \\
\hline $\begin{array}{l}\text { United } \\
\text { Arab } \\
\text { Emirates }\end{array}$ & 1.18 & 1.43 & $\begin{array}{l}\text { Mineral fuels and oil, cop- } \\
\text { per, plastics, fertilizers }\end{array}$ & $\begin{array}{l}\text { Pearls, precious stones } \\
\text { and metals, iron and steel, } \\
\text { edible fruits, vehicles }\end{array}$ \\
\hline
\end{tabular}

Notes Compiled by author with data from un Comtrade Database on international trade (https://comtrade.un.org).

billion or 9.1\% of South Africa's total exports in 2018. In February 2019, the Asian region accepted $\mathrm{R}$ 31,004 million worth of goods, an increase of R 1,252 million from January 2019 and imported R 42,071 million, down from $\mathrm{R} 7,589$ million from January 2019, thereby experiencing a trade deficit of R 11,067 million compared to R 19,909 million deficit recorded in January 2019. This is according to a report released by South African Revenue Services in March 2019. Bilateral trade between Japan and South Africa had been expanding since the establishment of full diplomatic relations in 1992. The Tokyo Agenda for Action cemented the trade relationship and greater co-operation between South Africa and Japan. South Africa exports mainly primary products such as mineral products, base metals and agricultural produce to Japan whilst importing technologyintensive goods from Japan. While the Japan-South Korea trade relationship is not particularly in good shape, South Africa has good relations with the country, with Japan being South Africa's fifth top trading partner taking $4.7 \%$ worth of exports from South Africa and is followed by South Korea with $2 \%$. The latest South African Revenue Services trade statistics show that China, Germany, United Kingdom, United States, and Japan were South Africa's top export destinations for July 2019 and China, Germany, United States, India, Saudi Arabia were top import destinations. 
In the African region, South Africa, Botswana, Namibia, Mozambique, Zambia, and Zimbabwe form a part of the SADC trade partnership. The African countries have a healthy trade relationship built on mutual goals based on economic, political, and trade interests. Botswana is South Africa's top trading partner in the African region, followed by Namibia, Mozambique, Zambia, and Zimbabwe. Through the signing of the SADC trade protocol, the FTA has eliminated about $85 \%$ of customs duties on trade in goods produced in the region allowing free movement of goods.

\section{Methodology}

We borrow our empirical specification from Bernard and Durlauf (1996) and Evans and Karras (1996) who define convergence as a state in which the deviations of the real per capita GDP (i.e. $y_{1, t+i}, y_{2, t+i}, \ldots, y_{N, t+i}$ ) from their trading partner's per capita averages $\bar{y}_{t}$ can be expected to approach constant values as $i$ approaches infinity:

$$
\lim _{i \rightarrow \infty} E_{t}\left(y_{n, t+i}-\bar{y}_{t+i}\right)=\mu_{n} .
$$

From equation (1), convergence is assumed to exist if the series $y_{n, t+i}-$ $\bar{y}_{t+i}$ is a stationary, $\mathrm{I}(\mathrm{o})$ process, otherwise if the series is integrated of order I(1) or higher, then the real per capita GDP's diverge from each other over the long-run. Suppose we define $z_{t}=y_{n, t+i}-\bar{y}_{t+i}$ and consider the following stochastic model for $z_{t}$ :

$$
z_{t}=d(t)+e_{t}
$$

where $d(t)$ is a time varying determinist component which we assume to unknown and $e_{t}$ is a well-behaved disturbance term with properties $N\left(\mathrm{o}, \sigma^{2}\right)$. Following Christopoulos and Leon-Ledesma (2010) and Ender and Lee (2012) we employ a single frequency Fourier series to approximate the unknown number of breaks in the unknown form of $d(t)$ as:

$$
d(t)=\alpha_{\mathrm{o}}+\alpha_{1} \sin \frac{2 \pi k t}{T}+\alpha_{2} \cos \frac{2 \pi k t}{T},
$$

where $k$ is the frequency and 1 and 2 measure the amplitude and displacement of the frequency component. In substituting (3) into (2) results in the following formal testing model:

$$
z_{t}=\alpha_{\mathrm{o}}+\alpha_{1} \sin \frac{2 \pi k t}{T}+\alpha_{2} \cos \frac{2 \pi k t}{T}+e_{t} .
$$

And from equation (4), the unit root null hypothesis is tested as:

но: $e_{t}=v_{t}, v_{t}=v_{t-1}+h_{t}$, 
where $h_{t}$ is assumed to be integrated of order I(o) with a zero mean. The unit root testing procedure is then carried out in three steps as outlined in Christopoulos and Leon-Ledesma (2010). Under the first step, we estimate regression (5) using values of $\mathrm{k}$ ranging from 1 to 5 and determine the optimal value of $k$ (i.e. $k^{\star}$ ) as being associated with the regression which produces the lowest sum of squared residuals (SSR). Once $k^{\star}$ is determined, then we extract the residuals from the corresponding estimated regression:

$$
\hat{e}_{t}=z_{t}-\left[\hat{\alpha}_{\mathrm{o}}+\hat{\alpha}_{1} \sin \frac{2 \pi k t}{T}+\hat{\alpha}_{2} \cos \frac{2 \pi k t}{T}\right] .
$$

Under the second step, we test the residuals defined in equation (6) and use two unit testing regressions to examine the integration properties. The first test is based on the conventional ADF unit root tests:

$$
e_{t}=\beta_{1} e_{t}+\sum_{k=1}^{n} \beta_{2} \Delta e_{t-1}+u_{t}, u_{t} \sim N\left(\mathrm{o}, \sigma^{2}\right) .
$$

The second testing procedure is based on that described in Kapetanois, Shin, and Snell (2003) and can be formulated as:

$$
e_{t}=\beta_{1} e_{t}^{3}+\sum_{k=1}^{n} \beta_{2} \Delta e_{t-1}+u_{t}, u_{t} \sim N\left(\mathrm{o}, \sigma^{2}\right) .
$$

From both regressions ( 7$)$ and (8), the unit root hypothesis is tested as

$$
\text { но: } \beta_{1}=\text { o. }
$$

And the test is evaluated by comparing the $t$-statistics associated with the 1 coefficient against the critical values reported in Christopoulos and Leon-Ledesma (2010). The third step of the modelling process involves validating the nonlinear trend captured by the Fourier function. This is achieved by testing the following hypothesis in regression (4):

$$
\text { Ho: } \alpha_{1}=\alpha_{2}=\text { o, }
$$

which is then evaluated using a $F$-test denote as $F\left(k^{\star}\right)$ and we use the critical values reported in Enders and Lee (2012). If the null hypothesis is rejected then we can be confident that the series is stationary around a deterministic function.

\section{Data and Empirical Analysis}

\section{DATA DESCRIPTION}

The data used in our study has been sourced from the World Bank online statistical base and we collect a total of 16 time series variables corre- 
TABLE 2 Summary Statistics of per Capita GDP Differences between South Africa and Her Trading Partners

\begin{tabular}{lrrrrrrr}
\hline Country & $(1)$ & $(2)$ & $(3)$ & $(4)$ & $(5)$ & $(6)$ & \\
\hline Belgium & -1.41 & -1.23 & 2.84 & -5.92 & -0.22 & 2.18 & 0.34 \\
Botswana & -4.55 & -2.89 & 6.54 & -23.47 & 5.68 & 16.18 & 0.00 \\
China & -5.96 & -6.99 & 27.86 & -17.38 & 7.14 & 205.50 & 0.00 \\
Germany & -1.48 & -1.31 & 3.20 & -7.77 & 2.89 & 1.78 & 0.41 \\
India & -2.44 & -2.35 & 8.61 & -9.35 & 3.87 & 3.69 & 0.16 \\
Japan & -2.25 & -1.73 & 6.44 & -11.02 & 3.68 & 0.92 & 0.63 \\
Mozambique & -2.31 & -2.47 & 12.88 & -15.18 & 5.19 & 7.21 & 0.03 \\
Namibia & -0.70 & -0.63 & 5.17 & -8.87 & 3.21 & 3.10 & 0.21 \\
Netherlands & -1.28 & -1.53 & 4.03 & -6.20 & 2.55 & 1.33 & 0.51 \\
South Korea & -5.15 & -4.42 & 7.12 & -16.10 & 4.65 & 0.03 & 0.98 \\
UAE & 2.22 & 1.68 & 17.25 & -14.35 & 6.85 & 0.13 & 0.94 \\
UK & -1.15 & -1.21 & 6.04 & -8.70 & 3.02 & 0.00 & 0.99 \\
Us & -1.14 & -0.90 & 5.11 & -8.15 & 2.86 & 0.15 & 0.93 \\
Zambia & 0.56 & -0.15 & 11.66 & -9.69 & 4.17 & 1.48 & 0.48 \\
Zimbabwe & 0.11 & -0.31 & 20.31 & -16.51 & 7.45 & 0.89 & 0.64 \\
\hline
\end{tabular}

Notes Column headings are as follows: (1) mean, (2) median, (3) maximum, (4) minimum, (5) standard deviation, (6) Jв, (7) probability.

sponding to the per capita GDP growth rates collected for South Africa and her 15 main trade partners i.e. Belgium, Botswana, China, Germany, India, Japan, Mozambique, Namibia, Netherlands, South Korea, United Arab Emirates (UAE), United Kingdom (UK), United States (Us), Zambia and Zimbabwe. The series covers a period of 1961 to 2018 with the exception of Germany (1971-2018), Mozambique (1981-2018), Namibia (19812018) and the UAE (1975-2018). Our empirical series is constructed by subtracting the per capita GDP of the individual trading partners from the South Africa's per capita GDP with the summary statistics of the resulting series being reported in table 2 and their time series plots being provided in figure 1.

As can be observed from table 2, the averages of per capita GDP differences are negative between South African and her major trading partners with the exception of UAE, Zambia and Zimbabwe. Moreover, figure 1 more-or-less shows that time series plot for the income differences between South Africa and her trading partners are not monotonic in nature 


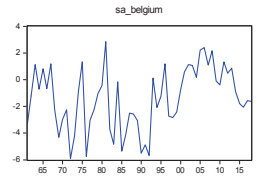

SA_INDAA

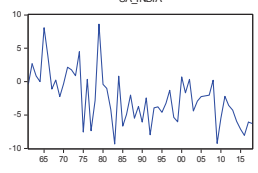

sa_namibia

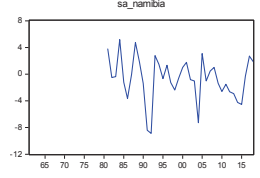

SA_US

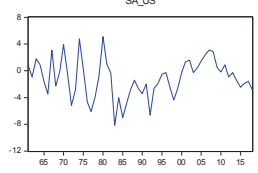

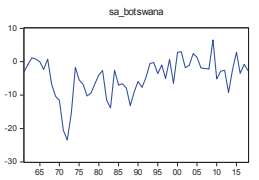

SA_JAPAN

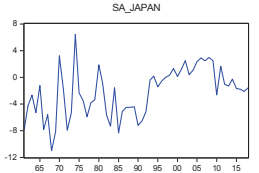

sa_netherlands

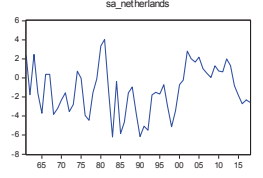

SA_ZAMBIA

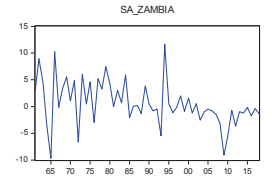

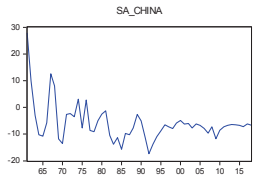

sa korea

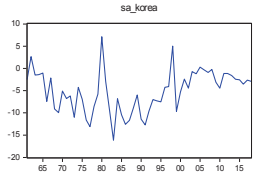

sa_UAE

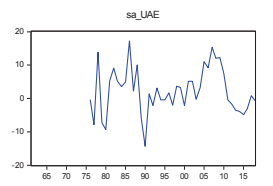

SA_ZIMBABAWE

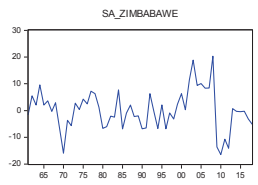

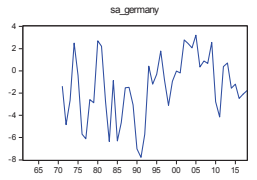

sa_mozambique

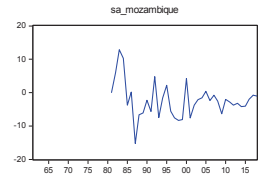

SA_UK

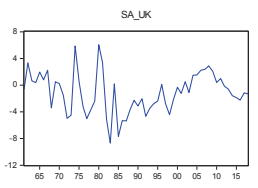

FIgURE 1 Time Series Plots of per Capita GDP Differences between South Africa and Her Trading Partners

and appear to plagued with a number of structural breaks as well as asymmetries over the long-run.

\section{EMPIRICAL ANALYSIS}

Table 3 presents the conventional unit root tests results for the ADF unit root tests along with the ESTAR unit root tests of Kapetanois, Shin, and Snell (2001). Note that we perform the both ADF and Kss tests on our series of per capita GDP differences using HAC variance-covariance matrix to deal with possible serial correlation and heteroscedasticity which may exist in the unit root testing regressions. The practicality of this approach to unit root tests is expounded in the studies of Kew and Harris (2009) as well as Demetrescu (2010). Note that we also add lags differences of the per capita GDP differences as an additional measure of robustness, with the optimal lag lengths being selected through a minimization of the modified Schwartz (sc) information criterion. From the results presented in table 3, both ADF and Kss test statistics reject their respective null hypotheses of unit root processes in favour of stationary series in all cases with the exception of the ADF test performed on per capita GDP differences between South Africa and Japan. Collectively, the results insinuate that South Africa tends to converge, over the long-run, towards 
TABLE 3 Conventional Unit Root Tests

\begin{tabular}{|c|c|c|c|c|c|}
\hline Country & $\mathrm{ADF}$ & Kss & Country & $\mathrm{ADF}$ & Kss \\
\hline Belgium & $-4.59^{* * *}(0)$ & $-2.48^{\star *}(1)$ & Netherlands & $4 \cdot 31^{* * *}(0)$ & $-3.53^{\star * *}(3)$ \\
\hline Botswana & $-5.49^{* * *}(3)$ & $-2.12^{\star}(2)$ & South Korea & $-4.27^{* * *}(0)$ & $3.15^{\star * *}(\mathrm{o})$ \\
\hline China & $6.62^{\star * \star}(0)$ & $-3 \cdot 42^{* \star *}(1)$ & UAE & $-4.56^{* * *}(0)$ & $-3.56^{\star * *}(1)$ \\
\hline Germany & $-3.92^{\star * \star}(0)$ & $-2.88^{\star \star \star}(0)$ & $\mathrm{UK}$ & $-4.84^{\star * \star}(0)$ & $-4.08^{\star \star \star}(0)$ \\
\hline India & $-5.38^{\star * \star}(0)$ & $-2.68^{\star \star}(1)$ & Us & $-4.63^{* * *}(0)$ & $-3.46^{\star * *}(0)$ \\
\hline Japan & $1.87(3)$ & $-2.22^{\star \star}(2)$ & Zambia & $-4.68^{\star \star \star}(1)$ & $-3.02^{\star * \star}(1)$ \\
\hline Mozambique & $-4 \cdot 32^{\star * \star}(0)$ & $-2.63^{\star \star \star}(0)$ & Zimbabwe & $-4.61^{\star \star \star}(0)$ & $-4.55^{\star * \star}(1)$ \\
\hline Namibia & $-4.84^{* * *}(0)$ & $-3.95^{* * *}(1)$ & Netherlands & $4 \cdot 31^{* * *}(0)$ & $-3.53^{\star * *}(3)$ \\
\hline
\end{tabular}

NOTES ${ }^{* * *},{ }^{* *}$, and ${ }^{\star}$ denote the 1 percent, 5 percent and 10 percent significance levels, respectively.

the per capita GDP growth differences with both lower income (i.e. Zambia and Zimbabwe) and higher income (i.e. Belgium, Botswana, China, Germany, India, Japan, Mozambique, Namibia, Netherlands, South Korea, the UAE, the UK and the Us) trading partners. However, these findings are not altogether conclusive as the ADF and kss are notoriously known for ignoring important structural breaks in the data which may results in Type 1 error where the null hypothesis of a unit root can be wrongly rejected in favour of the stationary alternative (Enders and Lee 2012).

In view of the possible spurious results obtained from the conventional unit root tests, we proceed to report the findings obtained from our Fourier-based testing procedures. To re-call, we prefer the FF F unit root tests over other structural break unit root tests, as we do not need to know 'a priori' the exact break-dates and neither do we need to be concerned about the number of structural breaks existing in the data. Table 4 presents the findings obtained from the FFF-based tests for the ADF (i.e. FADF) and the KSS (i.e. FKSS) as described in Christopoulos and Leon-Ledesma (2010). The modelling process of the FFF-based test is instigate by selecting the optimal frequency, $k^{\star}$, which is determined by the 'Fourier regression' which produces the lowest SSR after estimating across a range, $1<k<5$. These values are reported in the second and third columns of table 4 , and as can be observed, the optimal frequency differ amongst the data but are constrained to $k^{*}=2,4,5$. The fourth and fifth columns present the FADF and F Kss unit root tests statistics. Note 
TABLE 4 FFF-Based Results

\begin{tabular}{lrrrrr}
\hline Country & Min SSR & \multicolumn{1}{c}{$k^{\star}$} & FADF & F KSS & $F\left(k^{\star}\right)$ \\
\hline Belgium & 327.85 & 4 & $-9.05^{* * *}(1)$ & $-3.34^{* * *}(1)$ & $23.54^{* * *}$ \\
Botswana & 1404.38 & 4 & $-5.70^{* * *}(3)$ & $-2.89^{* *}(3)$ & $27.94^{* * *}$ \\
China & 2150.10 & 4 & $-7.49^{* * *}(0)$ & $-3.23^{* * *}(2)$ & $35.48^{* * *}$ \\
Germany & 394.99 & 5 & $-7.53^{* * *}(1)$ & $-3.86^{* * *}(2)$ & 6.92 \\
India & 1173.69 & 2 & $-7.30^{* * *}(4)$ & $-2.81^{* *}(3)$ & $17.64^{* * *}$ \\
Japan & 801.20 & 5 & $-8.12^{* * *}(2)$ & $-3.16^{* * *}(3)$ & $26.67^{* * *}$ \\
Mozambique & 1310.59 & 5 & $-6.44^{* * *}(1)$ & $-2.96^{* * *}(2)$ & $7.23^{*}$ \\
Namibia & 562.30 & 5 & $-6.31^{* * *}(4)$ & $-2.19^{*}(3)$ & $8.74^{*}$ \\
Netherlands & 342.18 & 2 & $-6.37^{* * *}(4)$ & $-4.52^{* * *}(6)$ & $19.29^{* * *}$ \\
South Korea & 1215.66 & 4 & $-6.96^{* * *}(2)$ & $-3.50^{* * *}(2)$ & $35.68^{* * *}$ \\
UAE & 2574.34 & 5 & $-10.45^{* * *}(0)$ & $-6.14^{* * *}(0)$ & $6.54^{*}$ \\
UK & 612.36 & 4 & $8.09^{* * *}(2)$ & $-3.38^{* * *}(3)$ & $16.08^{* * *}$ \\
Us & 513.26 & 5 & $-7.35^{* * *}(2)$ & $-4.64^{* * *}(3)$ & $26.48^{* * *}$ \\
Zambia & 1932.37 & 5 & $-9.08^{* * *}(3)$ & $-1.29(3)$ & $19.84^{* * *}$ \\
Zimbabwe & 3419.39 & 4 & $6.13^{* * *}(3)$ & $-1.11(1)$ & $16.14^{* * *}$ \\
\hline
\end{tabular}

NOTES ${ }^{* * *},{ }^{* *}$, and ${ }^{*}$ denote the 1 percent, 5 percent and 10 percent significance levels, respectively.

that the FADF test statistics, which only account for smooth structural breaks, unanimously produces statistics which manage to reject the unit root null hypothesis at all levels of significance. However, the F Kss test statistics which account for both ESTAR-type nonlinearities and smooth structural breaks, reject the unit root null hypothesis for all series with the exception of the per capita GDP growth differences between South Africa and (i) Zambia and (ii) Zimbabwe. The final column reports the $F\left(k^{\star}\right)$ statistics which tests for the presence of significant nonlinearities in the data series. All reported $F$-statistics manage to reject the null hypothesis of no nonlinear trends in the data and favours the use of Fourier functions in capturing such asymmetries in the data.

\section{Conclusions}

Convergence effects between developing or emerging economies and more industrialized countries has been the centrepiece of the debate on the growth dynamics. Our study sought to investigate the convergence effects between South Africa and her top 15 trading partners (i.e. Bel- 
gium, Botswana, China, Germany, India, Japan, Mozambique, Namibia, Netherlands, South Korea, the UAE, the UK, the us, Zambia and Zimbabwe) using unit root testing proposed framework as proposed by Quah (1993). In differing from previous studies, our study relied on more advanced Fourier-based unit root tests which are robust to asymmetries and unobserved smooth structural breaks. Our empirical approach examines the integration properties of the per capita GDP growth differences between South Africa and her individual trading partners.

Our preliminary analysis, constituting of conventional ADF and Kss unit root tests, provides overwhelming evidence of convergence effects between South Africa and all her main trading partners, regardless of whether the trading partners are more advanced or less advanced than South Africa. In proceeding to apply the more robust Fourierbased tests, particularly that which is robust to ESTAR-type asymmetries and smooth structural breaks, we observe convergence between South Africa and her more advanced, international trading partners (i.e. Belgium, Botswana, China, Germany, India, Japan, Mozambique, Namibia, Netherlands, South Korea, the UAE, the UK and the Us) whereas lacking evidence of convergence effects with her less developed, African trading partners (i.e. Zambia and Zimbabwe)). The policy implications from our findings confirm trade as an avenue through which South Africa can 'catch-up' to other more industrialized economies. The specific trade products which South Africa needs to focus on as a means of facilitating a quicker convergence path towards the growth rates of more industrialized economies, is an endeavor which we reserve for future research opportunities.

\section{References}

Arbia, G., R. Basile, and G. Piras. 2005. 'Using Spatial Panel Data in Modelling Regional Growth and Convergence.' Is AE Working Papers No. 55, Italian National Institute of Statistics, Rome.

Bai, J., and S. Ng. 2004. 'A PANIC Attack on Unit Roots and Cointegration.' Econometrica 72 (4): 1127-77.

Barro, R. 1991. 'Economic Growth in a Cross Section of Countries.' Quarterly Journal of Economics 106 (2): 223-51.

Barro, R., and X. Sala-i-Martin. 1992. 'Convergence.' Journal of Political Economy 100 (2): 223-51.

Baumol, W. 1986. 'Productivity Growth, Convergence, and Welfare: What the Long Run Data Show. The American Economic Review 76 (5): 107285 . 
Ben-David D. 1992. 'Trade and Convergence among Countries.' Journal of International Economics 40 (3-4): 279-98.

Bernard, A., and S. Durlauf. 1996. 'Interpreting Tests of the Convergence Hypothesis.' Journal of Econometrics 71 (1-2): 161-73.

Burgess, R. 2009. 'The South African Development Community's Macroeconomic Convergence.' I M F Staff Position Note 2009/14, International Monetary Fund, Washington, DC.

Charles, A., O. Darné, and J. Hoarau. 2010. 'Convergence of Real per Capita GDP within Comes A Countries: A Panel Unit Root Evidence.' Annals of Regional Science 49 (1): 53-71.

Cuñado, J., and F. Pérez de Gracia. 2006. 'Real Convergence in Africa in the Second Half of the 2oth Century.' Journal of Economics and Business 58 (2): $153-67$.

De Long, J. 1988. 'Productivity Growth, Convergence, and Welfare: Comment.' The American Economic Review 78 (5): 1138-54.

Demetrescu, M. 2010. 'On the Dickey Fuller Test with White Standard Errors.' Statistical Papers 51 (11): 11-25.

Dobson, S., J. Goddard, and C. Ramlogan. 2003. 'Convergence in Developing Countries: Evidence from Panel Unit Root Tests.' Economics Discussion Paper, University of Otago, Dunedin.

Enders, W., and J. Lee. 2012. 'The Flexible Fourier Form and Dickey-Fuller Type Unit Root Tests.' Economics Letters 117 (1): 196-99.

Evans, P., and G. Karras. 1996. 'Convergence Revised.' Journal of Monetary Economics 37 (2-3): 249-65.

Friedman, M. 1992. 'Do Old Fallacies Ever Die?' Journal of Economic Literature 30 (4): 2129-32.

Guetat, I., and F. Serranito. 2007. 'Income Convergence within the MENA Countries: A Panel Unit Root Approach.' The Quarterly Review of Economics and Finance 46 (5): 685-706.

Hadizadeh, A. 2019. 'Testing the Convergence Clubs Hypothesis among MENA Countries.' Iranian Economic Review 23 (2): 437-49.

Hammouda, H. B., S. N. Karigi, A. E. Njuguna, and M. S. Jallab. 2007. 'Does Macroeconomic Convergence Lead to Growth? The Case of Africa.' http://www.ku.ac.ke/schools/economics/images/Angelina.pdf

Harvey, C. 2000. 'Macroeconomic Policy and Trade Integration in Southern Africa.' Working Paper oo039, University of Cape Town, Cape Town.

Im, K. S., M. H. Pesaran, and Y. Shin. 2003. 'Testing for Unit Roots in Heterogeneous Panels.' Journal of Econometrics 115 (1): 53-74.

Kapetanois, G., Y. Shin, and A. Snell. 2003. 'Testing for a Unit Root in a Nonlinear STA R Framework.' Journal of Econometrics 112 (2): 359-79.

Khan, M. S., and M. S. Kumar. 1993. 'Public and Private Investment and 
the Convergence of per Capita Incomes in Developing Countries.' I MF Working Paper 93/51, International Monetary Fund, Washington, DC.

Levin, A., C. F. Lin, and C. S. J. Chu. 2002. 'Unit Root Test in Panel Data: Asymptotic and Finite Sample Properties.' Journal of Econometrics 108 (1): $1-24$.

McCarthy, C., and S. du Plessis. 2001. Macroeconomic Convergence in SADC. Pretoria: Committee of Central Bank Governors in SADC.

Mankiw, N., D. Romer, and D. Weil. 1992. 'A Contribution to the Empirics of Economic Growth.' Quarterly Journal of Economics 107 (2): 407-37.

McCoskey, S. K. 2002. 'Convergence in Sub-Saharan Africa: A NonStationary Panel Data Approach.' Applied Economics 34 (7): 819-29.

McCoskey, S., and C. Kao. 1998. 'A Residual-Based Test of the Null of Cointegration in Panel Data.' Econometric Reviews 17 (1): 57-84.

Nwosu, C. A., A. C. Njoku, L. Akunya, S. C. Ihekweme, and S. N. Marcus. 2013. 'Total Factor Productivity Convergence in Africa: Panel Unit Root Approach.' West African Journal of Industrial and Academic Research 8 (1): 139-48.

Paap, R., P. H. Franses, and D. van Dijk. 2005. 'Does Africa Grow Slower than Asia, Latin America and the Middle East? Evidence from a New Data-Based Classification Method.' Journal of Development Economics 77 (2): 553-70.

Perron, P. 1990. 'Testing for a Unit Root in a Time Series with a Changing Mean.' Journal of Business \& Economic Statistics 8 (2): 153-62.

Quah, D. 1993. 'Glaton's Fallacy and Tests of the Convergence Hypothesis.' Scandinavian Journal of Economics 95 (4): 427-43.

- 1996. 'Empirics for Growth and Distribution: Stratification, Polarization, and Convergence Clubs.' Journal of Economic Growth 2:27-59.

Rebelo, S. 1991. 'Long-Run Policy Analysis and Long-Run Growth.' Journal of Political Economy 99 (3): 500-21.

Romer, P. 1986. 'Increasing Returns and Long-Run Growth.' Journal of Political Economy 94 (5): 1002-37.

- 1990. 'Endogenous Technical Change.' Journal of Political Economy 98 (5): 70-102.

Rossouw, J. 2006. 'South Africa's Role in Macroeconomic Convergence in SA DC.' Paper presented at SA R B Conference 2006, Pretoria, 22-24 October.

Sachs, J., and A. Warner. 1999. 'The Big Rush, Natural Resource Booms and Growth.' Journal of Development Economics 59 (1): 43-76.

Sachs, J. D., N. Bajpai, and A. Ramiah. 2002. 'Understanding Regional Economic Growth in India.' Working Paper 88, Centre for International Development, Cambridge, MA. 
Sokoloff, K., and S. Engerman. 2000. 'History Lessons: Institutions, Factor Endowments, and Paths of Development in the New World.' The Journal of Economic Perspectives 14 (3): 217-32.

Verdoorn, J. P. 1993. 'On the Factors Determining the Growth of Labor Productivity'. In Italian Economic Papers, edited by L. Pasinetti, 2:5968. Oxford: Oxford University Press.

Yao, S., and Z. Zhang. 2001. 'On Regional Inequality and Diverging Clubs: A Case Study of Contemporary China.' Journal of Comparative Economics 29 (3): 466-84.

Zyuulu, I. 2010. 'Convergence in SADC and African Economic Integration Process: Prospects and Statistical Issues.' In Proceedings of the $S A R B / I F C$ Seminar on Economic and Financial Convergence en Route to Regional Economic Integration, 96-105. IFC Bulletins 32. Basel: Bank for International Settlements. 